JURNAL KETAHANAN NASIONAL

Vol.23, No.3, Desember 2017, Hal 280-299

DOI:http://dx.doi.org/ 10.22146/jkn.28124

ISSN:0853-9340(Print), ISSN:2527-9688(Online)

Online sejak 28 Desember 2015 di :http://jurnal.ugm.ac.id/JKN

VOLUME 23

No. 3, Desember 2017

Halaman 280-299

\title{
Peran Sarjana Membangun Desa (SMD) Dalam Peningkatan Ekonomi Masyarakat Dan Implikasinya Terhadap Ketahanan Ekonomi Masyarakat (Studi Pada Kelompok Peternak Gunungrejo Makmur, Kabupaten Lamongan - Jawa Timur)
}

\section{Nasrudin}

KAMMI Wilayah Yogyakarta

Email: nasrudin.craft@gmail.com

\section{Edhi Martono}

Fakultas Pertanian Universitas Gadjah Mada

Email: edhi.martono@ugm.ac.id

\author{
Subejo \\ Fakultas Pertanian Universitas Gadjah Mada \\ Email: subejo@ugm.ac.id
}

\begin{abstract}
This research studied about the role of Bachelors Builds Villages (SMD) to improved the economy of local community and its implication toward the community economy resilience, through the study of SMD at the cattle farm and poultry farm of Gunungrejo Makmur in Gunungrejo village, Kedungpring sub-district, Lamongan Regency, East Java Province. This research aimed to analyzed the role of SMD in enhancing the development of local community economy and its implication toward the community economy resilience.

This research used descriptive qualitative method. The data was colected by using a deep interviews, field observations, Focus Group Discussion (FGD), academic journals, documentation and literature review. The data was analyzed by using a reduction data technique, data presentation, interpretation and conclusion withdrawal.

The result showed that there were significant economy enhancements of local community in Gunungrejo Makmur which was involved in the cattle farm and poultry farm bussiness. Both of these two commodities were growing rapidly. The poultry commodities of Gunungrejo Makmur was especially became a model for many other farms whether in local or outside region. While the cattle farm commodity had been several times successfully awarded in the province as well as national level. Anything related to an unstable price and development problem had been able to overcome by the farmers through anticipatory measures to minimized losses. Finally the role of Bachelors Builds Villages (SMD) had been implication to the resilience community ecomony resilience in Gunungrejo Makmur group.
\end{abstract}

Keywords: Farmers Group, Bachelors Builds Villages (SMD), Community Economic Enhancement, Community Economic Resilience.

\begin{abstract}
ABSTRAK
Penelitian ini mengkaji tentang peran Sarjana Membangun Desa (SMD) terhadap peningkatan ekonomi masyarakat dan implikasinya pada ketahanan ekonomi masyarakat, dengan mengambil studi SMD pada kelompok peternak sapi potong dan ayam petelur Gunungrejo Makmur Desa Gunungrejo Kecamatan Kedungpring Kabupaten Lamongan, Provinsi Jawa Timur. Adapun tujuan daripada penelitian ini yaitu untuk menganalisis peran SMD terhadap peningkatan ekonomi masyarakat serta implikasinya pada ketahanan ekonomi masyarakat.
\end{abstract}


Nasrudin, Edhi Martono, Subejo -- Peran Sarjana Membangun Desa (SMD) Dalam Peningkatan Ekonomi Masyarakat Dan Implikasinya Terhadap Ketahanan Ekonomi Masyarakat (Studi Pada Kelompok Peternak Gunungrejo Makmur, Kabupaten Lamongan - Jawa Timur)

Metode yang digunakan pada penelitian ini yaitu metode deskriptif kualitatif, dengan teknik pengumpulan data berupa wawancara mendalam, observasi di lapangan, FGD (Focus Group Discussion), jurnal akademik dan dokumentasi serta studi kepustakaan. Teknik analisis data dalam penelitian ini yaitu reduksi data, penyajian data, interpretasi serta penarikan kesimpulan.

Hasil penelitian menunjukkan bahwa terjadi peningkatan ekonomi yang signifikan pada masyarakat terutama yang terlibat dalam usaha peternakan sapi potong maupun ayam petelur, serta kedua komoditas tersebut telah berkembang secara pesat. Untuk komoditas ayam petelur peternakan Gunungrejo Makmur terbukti sukses karena menjadi percontohan bagi banyak peternakan lain baik di daerah setempat maupun di luar daerah, sedangkan untuk komoditas sapi potong bukti suksesnya adalah beberapa kali telah berhasil mendapatkan penghargaan mulai tingkat provinsi sampai nasional. Adapun kendala-kendala utama seperti kendala harga yang tidak stabil dan kendala pengembangan, telah mampu diatasi oleh para peternak dengan langkah-langkah antisipatif untuk meminimalisasi kerugian. Secara ringkas adanya peran Sarjana Membangun Desa (SMD) tersebut telah berimplikasi pada ketahanan ekonomi masyarakat di kelompok peternak Gunungrejo Makmur.

Kata Kunci: Kelompok Peternak, Sarjana Membangun Desa (SMD), Peningkatan Ekonomi Masyarakat, Ketahanan Ekonomi Masyarakat

\section{PENGANTAR}

Indonesia telah memasuki era baru perdagangan bebas Asia Tenggara yang telah disepakati sejak satu dekade lalu atau saat ini dikenal dengan nama Masyarakat Ekonomi ASEAN (MEA). Inti dari adanya MEA adalah untuk membentuk kesatuan pasar dan basis produksi di kawasan Asia Tenggara dengan harapan, bahwa dengan adanya MEA maka arus investasi akan menyaingi negara seperti China, Amerika maupun negara-negara di benua Eropa. MEA sebagai bentuk kerjasama regional Asia Tenggara memiliki 10 anggota yaitu Indonesia, Malaysia, Singapura, Brunei Darusalam, Filipina, Laos, Vietnam, Thailand, Kamboja dan Myanmar (Jaygree, 2008: 210). Dalam implementasinya MEA memiliki visi untuk saling bahu-membahu meningkatkan perekonomian di masing-masing negara anggota dengan adanya kemudahan investasi, sektor ekspor-impor dengan tanpa dikenai bea cukai, serta saling membantu di sektor tenaga profesional.

Pertanyaan menarik yang sering muncul dari kalangan akademisi, para pengusaha maupun pemerintah adalah apa keuntungan dari adanya era baru MEA ini, terutama bagi kemajuan perekonomian Indonesia dan khususnya untuk para pelaku usaha mikro kecil dan menengah (UMKM). Hasil riset terbaru Organisasi Perburuhan Dunia (ILO) menyebutkan bahwa dengan dibukanya Masyarakat Ekonomi ASEAN akan memungkinkan untuk meningkatkan PDB sebesar 2,5\% dan lapangan kerja baru di Indonesia sebesar 1,9 Juta pada tahun 2015 (Miyamoto,2015:43).

Kondisi tersebut seharusnya menjadi kabar baik bagi negara-negara anggota MEA, terutama Indonesia karena setelah dibukanya kerjasama ini secara otomatis akan mengurangi pengangguran dan meningkatkan kesejahteraan masyarakat di kawasan Asia Tenggara khususnya Indonesia. Namun adanya kerjasama regional tersebut juga menuntut kemungkinan bahwa suatu negara akan semakin lemah ekonominya jika negara tersebut tidak memiliki rencana strategis dan penyiapan SDM yang bermutu untuk menghadapi pasar tunggal tersebut.

Secara geopolitik Indonesia merupakan negara dengan jumlah penduduk mencapai 254 juta dan merupakan penduduk terbesar atau sekitar $40,3 \%$ dari total penduduk pada negara-negara anggota MEA. Sejalan dengan hal tersebut menurut Morgenthau 
(2010:154) dalam bukunya Politik Antar Bangsa "demografi memiliki peran penting dalam kaitannya dengan national power, dan peningkatan kekuatan Ekonomi di negara tersebut, jika dan hanya jika negara tersebut mampu mengelolanya dengan baik". Artinya bahwa dengan adanya demografi yang melimpah dan dikelola dengan benar memungkinkan untuk menjadi negara yang stabil secara ekonomi serta mampu bersaing di era baru dalam hal ini adalah perdagangan bebas pada Masyarakat Ekonomi ASEAN.

Persaingan ekonomi abad 21 ditandai dengan adanya globalisasi ekonomi yang merupakan proses kegiatan ekonomi dan perdagangan dimana negara-negara dari seluruh dunia menjadi satu kekuatan pasar tunggal yang semakin terintegrasi dengan semakin minimalnya rintangan batas teritorial negara. Adanya globalisasi menuntut efisiensi dan daya saing dalam dunia usaha. Globalisasi juga menuntut persaingan bebas yang menganut konsep dekonsentrasi sehingga mau tidak mau perusahaan-perusahaan lokal harus memilki daya saing internasional. Daya saing ini bukan hanya menyangkut kemampuan bersaing memasok produk di pasar internasional tetapi juga di dalam pasar domestik untuk menghadapi pesaing dari luar negeri. Menurut Davidson (2005:3) dalam persaingan yang sehat dalam ekonomi pasar bebas memberikan empat keuntungan. Pertama, persaingan akan pemberian harga yang kompetitif. Kedua, adanya peningkatan kualitas hidup sebagai akibat dari inovasi yang secara terus-menerus. Ketiga, mendorong dan meningkatkan mobilitas masyarakat. Keempat, adanya efisiensi baik efisiensi produktif maupun efisiensi alokasi.
Selain persaingan ekonomi dalam era globalisasi, Sumber Daya Manusia (SDM) merupakan salah satu faktor yang sangat penting dalam kemajuan suatu negara terutama dari sisi kemajuan ekonomi. Hal ini terbukti di negara-negara maju dimana sumber daya manusia sangat berperan aktif dalam memajukan negaranya untuk menjadi penguasa dunia. Sumber Daya Manusia (SDM) merupakan salah satu faktor kunci dalam reformasi ekonomi, maksudnya yakni bagaimana suatu negara menciptakan sumber daya manusia yang berkualitas, memiliki keterampilan, kemampuan, kemauan dan pengetahuan serta jiwa daya saing yang tinggi dalam menghadapi persaingan global.

Indonesia masih menghadapi masalah yang cukup serius berkenaan dengan kualitas SDM. Terkait dengan kondisi tersebut SDM di Indonesia pada awalnya terjadi ketimpangan antara jumlah kesempatan kerja dan angkatan kerja yaitu pada masa krisis ekonomi 1998 jumlah angkatan kerja nasional sekitar 92,73 juta orang, sementara jumlah kesempatan kerja yang ada hanya sekitar 87,67 juta orang dan ada sekitar 5,06 juta orang penganggur terbuka (open unemployment). Angka tersebut meningkat terus selama krisis ekonomi hingga kini di tahun 2016 tercatat ada 7,4 juta pengangguran terbuka (Badan Pusat Statistik, 2016).

Dalam kancah persaingan global berdasarkan World Competitiveness Report tahun 2016-2017 tingkat SDM Indonesia menempati urutan ke-41 atau posisi yang cukup rendah dibandingkan negara-negara ASEAN yang diteliti, yaitu di bawah Singapura, Malaysia, dan Thailand (Schwab, 2016:7). Untuk itu perlu sumber daya manusia yang unggul, tangguh dan ulet serta mempunyai karakter yang baik. Jika pemuda bangsa mengalami kemunduran, hal tersebut ikut 
Nasrudin, Edhi Martono, Subejo -- Peran Sarjana Membangun Desa (SMD) Dalam Peningkatan Ekonomi Masyarakat Dan Implikasinya Terhadap Ketahanan Ekonomi Masyarakat (Studi Pada Kelompok Peternak Gunungrejo Makmur, Kabupaten Lamongan - Jawa Timur)

berdampak buruk pada kondisi bangsa. Oleh sebab itu, pemuda menjadi unsur yang penting dalam perkembangan bangsa dan negara (Shofa, 2016).

Di sisi lain dalam satu dekade ke depan Indonesia akan dikejutkan dengan adanya bonus demografi yang begitu besar, yaitu kondisi dimana jumlah penduduk usia produktif menempati posisi tertinggi. Untuk itu diperlukan perhatian khusus setidaknya rencana proyeksi dari pemerintah tentang arah bonus demografi tersebut, serta program yang seperti apa kiranya yang tepat, sehingga di saat Indonesia telah memasuki fase bonus demografi masyarakat dan para pemuda Indonesia telah siap bersaing di kancah regional maupun global.

Sementara itu pada aspek ketahanan ekonomi, bangsa Indonesia saat ini sedang menghadapi dua masalah serius yang perlu untuk segera ditemukan solusinya, masalah yang pertama adalah semakin tingginya tingkat kesenjangan ekonomi (rasio gini) karena selama ini pertumbuhan ekonomi secara pesat hanya terjadi di kota-kota besar yang artinya pertumbuhan ekonomi terjadi secara eksklusif, sehingga adanya pertumbuhan ekonomi tersebut kurang dapat dinikmati masyarakat secara keseluruhan. Berdasarkan data Bank Dunia tahun 2016 manfaat pertumbuhan ekonomi lebih dinikmati oleh $20 \%$ orang terkaya, sisanya $80 \%$ atau sekitar 205 juta penduduk Indonesia merasa masih tertinggal (Bank Dunia, 2016:9). Kondisi ini berbeda dengan pendapat Yusuf (2016:287) yang menjelaskan bahwa harusnya semakin tinggi laju pertumbuhan ekonomi suatu negara maka dapat menjadi tolok ukur kesejahteraan rakyat dan kemajuan sebuah bangsa.

Masalah yang kedua adalah masih tingginya ketergantungan impor khususnya daging terhadap negara lain hal ini dikarenakan kebutuhan daging dalam negeri yang cukup tinggi, menurut Jiuhardi (2016: 78) sampai saat ini Indonesia masih kekurangan pasokan daging sapi hingga 35 persen atau sekitar135,1 ribu ton dari kebutuhan 385 ribu ton. Artinya tingkat pasokan daging dari para peternak dalam negeri masih belum mencukupi konsumsi daging nasional. Di sisi lain Indonesia memiliki banyak peternak lokal walaupun pada kenyataannya peternak tersebut hanya berskala rumah tangga, dan dalam hal ekonomis hasil beternak tersebut belum cukup untuk memenuhi kebutuhan sehari-hari dikarenakan jumlah peternaknya yang belum berorientasi bisnis dan harga jual ternak di pasaran yang sering mengalami fluktuasi.

Melihat kondisi tersebut maka diperlukan kebijakan yang tepat dari pemerintah dan partisipasi aktif seluruh elemen masyarakat serta para akademisi, dengan cara bersamasama melakukan sinergi positif sebagai upaya meningkatkan produktivitas masyarakat dalam peningkatan ekonomi di Indonesia. Menurut Yusuf (2016:287), produktivitas ekonomi harus sesuai dengan potensi yang ada di dalam masyarakat sehingga arah kebijakan yang akan dibuat mampu melihat realitas yang ada di dalam masyarakat. Lebih lanjut pentingnya pembangunan ekonomi juga disampaikan oleh Prasetyo (2013:1), menurutnya pembangunan pertanian merupakan bagian dari pembangunan nasional yang sangat penting dan harus menjadi prioritas. Terlebih dalam pelaksanaannya upaya tersebut telah tertuang dalam rencana strategis kementerian pertanian tahun 2010-2014 yang menyangkut bidang peternakan yaitu tentang swasembada daging secara berkelanjutan. Hal tersebut berangkat daripada masyarakat Indonesia 
yang mayoritas adalah petani dan peternak. Senada dengan kondisi tersebut, peternakan sapi potong di Indonesia menurut Soedjana (2005), didominasi oleh peternakan rakyat di pedesaan yang pada umumnya berskala kecil dan memiliki produktivitas rendah.

Program Sarjana Membangun Desa (SMD) merupakan salah satu program dari Direktorat Jendral Peternakan dan Kesehatan, Kementerian Pertanian RI yang tujuannya adalah untuk memberdayakan kelompok tani ternak yang dilakukan dengan menempatkan para lulusan sarjana peternakan dan kedokteran hewan serta D-3 Ilmu-ilmu peternakan maupun kedokteran hewan untuk ikut serta mendampingi dan mendidik kelompokkelompok tani ternak di seluruh Indonesia (Direktorat Jendral Peternakan, 2007).

Dalam perjalanannya program Sarjana Membangun Desa (SMD) telah dilaksanakan sejak tahun 2007 dengan fokus pada pengembangan usaha ternak sapi potong yang tujuan utamanya adalah untuk mendukung swasembada daging sapi. Diharapkan dengan adanya program SMD ini dapat terjadi transfer ilmu pengetahuan teknologi dari perguruan tinggi ke masyarakat lewat seorang Pendamping kelompok atau biasa disebut SMD, sehingga mampu meningkatkan jiwa kewirausahaan baik para penerima program SMD maupun masyarakat yang terdampingi dari adanya program tersebut.

Peran Sarjana Membangun Desa (SMD) pada penelitian ini sebagai subjek penggerak ekonomi masyarakat karena subjeknya merupakan para pemuda lulusan perguruan tinggi dengan bidang peternakan atau kedokteran hewan, yang kemudian ikut berpartisipasi aktif dalam pegembangan sektor peternakan di daerah. Di sisi lain tak sedikit dari para SMD ini perannya malah menjadi pelopor kemajuan dalam program pemberdayaan masyarakat maupun peningkatan ekonomi seperti yang dicontohkan Drh Suparto pada peternakan Gunungrejo Makmur. Adanya SMD ini diharapkan mampu melahirkan model usaha peternakan yang berbasis agribisnis dan memiliki output daya saing baik secara kualitas maupun kuantitas, di sisi lain konsep SMD merupakan bentuk pembangunan ekonomi secara inklusif yang berfokus di pedesaan, lebih jauh jika dikaji secara makro kesuksesan dari peran SMD dapat mengantarkan Indonesia pada swasembada daging yang berimplikasi pada ketahanan ekonomi.

Pada penelitian ini, peran SMD yang menjadi objek penelitian adalah kelompok peternak Gunungrejo Makmur Desa Gunungrejo, Kecamatan Kedungpring, Kabupaten Lamongan, Jawa Timur, dengan komoditas ternak sapi potong dan ayam petelur. Pemilihan objek tersebut dikarenakan kelompok peternak Gunungrejo Makmur telah sukses bersama seorang pendamping Sarjana Membangun Desa yang menerapkan sistem peternakan terpadu dan mampu meningkatkan perekonomian bagi masyarakat terutama para peternak yang tergabung di dalamnya, serta mampu menjadi peternakan percontohan dan beberapa kali pernah menjuarai kontes sapi tingkat wilayah hingga nasional. Terlebih dalam tahap pengembangan, kelompok ternak Gunungrejo Makmur telah memiliki andil dalam menjaga suplai daging sapi di Jawa Timur dan menjadi wilayah sentra peternakan ayam petelur di Kabupaten Lamongan.

Melalui uraian latar belakang di atas maka dipandang penting untuk diadakan penelitian mengenai peran Sarjana Membangun Desa (SMD) terhadap peningkatan ekonomi masyarakat dan implikasinya terhadap 
Nasrudin, Edhi Martono, Subejo -- Peran Sarjana Membangun Desa (SMD) Dalam Peningkatan Ekonomi Masyarakat Dan Implikasinya Terhadap Ketahanan Ekonomi Masyarakat (Studi Pada Kelompok Peternak Gunungrejo Makmur, Kabupaten Lamongan - Jawa Timur)

ketahanan ekonomi masyarakat, studi tentang SMD di kelompok peternak Gunungrejo Makmur Kabupaten Lamongan, serta diharapkan melaui penelitian ini outputnya dapat membawa kesejahteraan bagi masyarakat Indonesia yang imbasnya adalah tercapainya ketahanan ekonomi masyarakat di Indonesia.

Adapun rumusan masalah pada penelitian ini yaitu (1) Bagaimana peran Sarjana Membangun Desa terhadap peningkatan ekonomi masyarakat pada peternakan Gunungrejo Makmur, (2) Apa saja kendala Sarjana Membangun Desa dalam upaya peningkatan ekonomi masyarakat pada peternakan Gunungrejo Makmur, (3) Bagaimana implikasi peran Sarjana Membangun Desa terhadap peningkatan ketahanan Ekonomi masyarakat pada peternakan Gunungrejo Makmur.

Penelitian ini merupakan penelitian kualitatif dengan pemaparan secara deskriptif. Pendekatan penelitian yang digunakan adalah studi pada suatu permasalahan yang terjadi di masyarakat. Pengumpulan data dalam penelitian ini menggunakan observasi, wawancara, FGD, studi dokumentasi dan studi kepustakaan. Prosedur teknik analisis data dalam penelitian ini, yaitu (1) reduksi data, (2) penyajian data, (3) interpretasi data, dan (4) penarikan kesimpulan.

\section{PEMBAHASAN \\ Profil Desa Gunungrejo}

Desa Gunungrejo merupakan desa yang terletak di ujung barat Kabupaten Lamongan yang berada di bawah wilayah administratif Kecamatan Kedungpring. Walaupun Desa Gunungrejo terletak hampir diperbatasan ujung barat Kabupaten Lamongan, dimana jarak dari Desa Gunungrejo pusat Kabupaten Lamongan kurang lebih $32 \mathrm{Km}$, akan tetapi sebelah utara Desa Gunungrejo dekat dengan Kota Babat, dimana kota tersebut merupakan kecamatan yang masih berada di bawah Kabupaten Lamongan, dan merupakan kota terbesar kedua setelah Kabupaten Lamongan.

Jika dilihat dari pertumbuhan ekonomi maupun jalur transportasi, Kota Babat memiliki peranan strategis karena Kota Babat terletak pada jalur persimpangan antara SurabayaBojonegoro-Cepu-Jombang serta Tuban, sehingga kondisi geografis ini merupakan

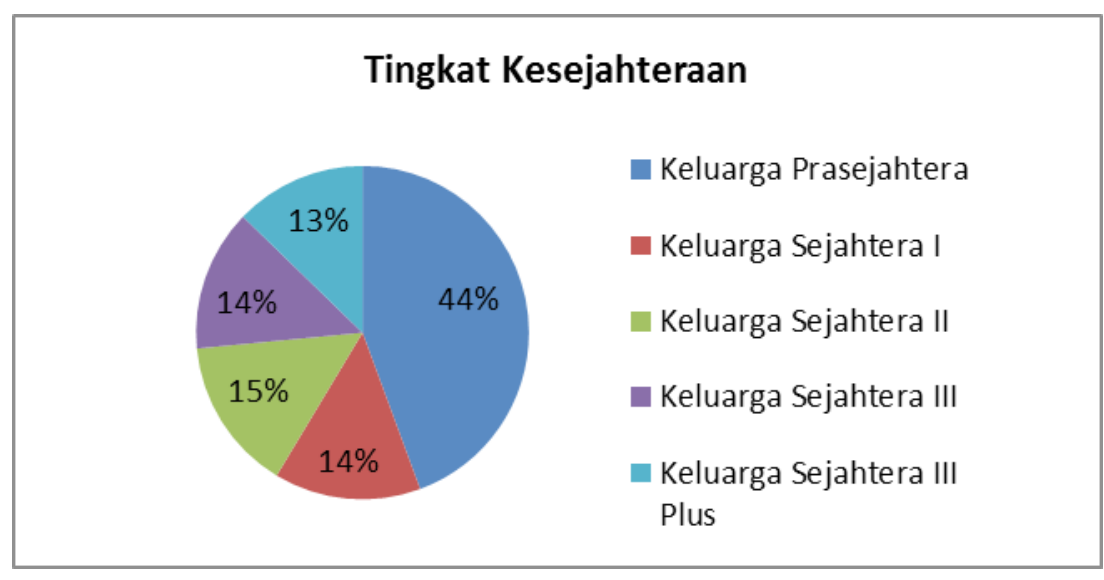

Sumber: Buku Laporan Tingkat Perkembangan Desa Tahun 2015 
Gambar 2

Tingkat Pendidikan Masyarakat Desa Gunungrejo

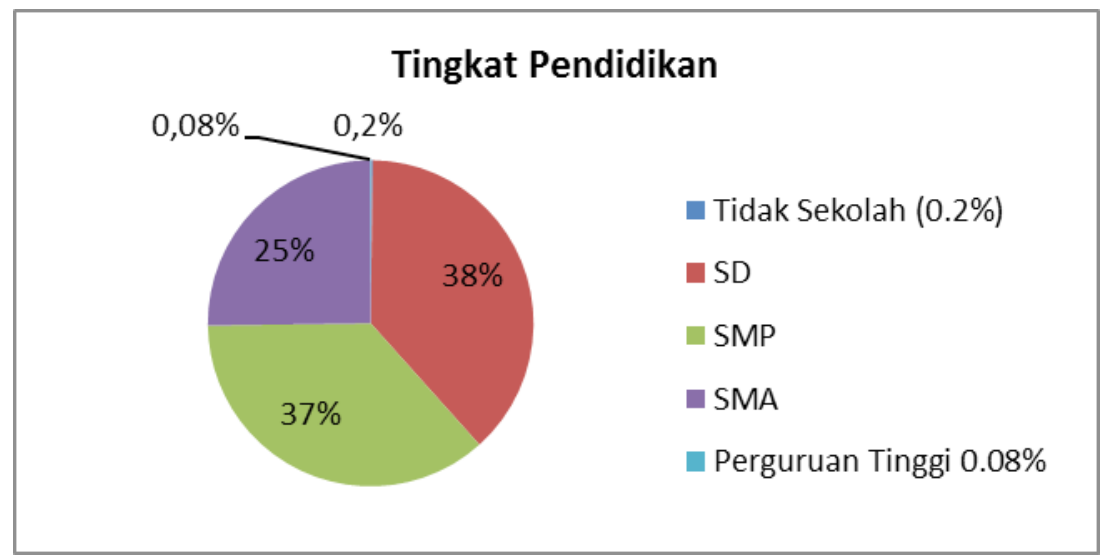

Sumber: Buku Laporan Profil Desa Tahun 2015

modal aset yang besar untuk pengembangan bisnis di sekitar wilayah tersebut salah satunya pengembangan sektor peternakan di Desa Gunungrejo, Kecamatan Kedungpring. Secara Geografis posisi Desa Gunungrejo terletak pada koordinat: 708'09.7'S 112¹0'27.0”E.

Berdasarkan laporan tingkat perkembangan desa tahun 2015, Desa Gunungrejo memiliki sebanyak 904 kepala keluarga (KK) dengan total jumlah penduduk desa sebesar 3.884 jiwa, dengan struktur mata pencarian mayoritas adalah di sektor pertanian dan sektor peternakan, baik peternakan sekala besar maupun kecil, sedangkan selebihnya bergerak pada sektor jasa/perdagangan dan hanya beberapa yang bergerak di sektor industri. Adapun tingkat kesejahteraan keluarga masyarakat Desa Gunungrejo ditunjukkan pada gambar 1 .

Gambar 1 tersebut menunjukkan bahwa tingkat kesejahteraan penduduk Desa Gunungrejo memiliki tingkat kesejahteraan yang cukup merata, hanya saja untuk keluarga prasejahtera memiliki jumlah yang paling tinggi. Sementara kondisi pendidikan di Desa Gunungrejo merujuk pada tingkat pendidikan dari keseluruhan masyarakat desa Gunungrejo. Adapun data tingkat perkembangan Desa Gunungrejo tahun 2015, di sektor pendidikan disajikan pada gambar 2.

Dari gambar 2 tersebut dapat diketahui bahwa tingkat pendidikan pada penduduk Desa Gunungrejo mayoritas adalah lulusan dari sekolah menengah dan hanya sedikit yang merupakan lulusan dari perguruan tinggi, bahkan proporsi terbanyak adalah lulusan Sekolah Dasar (SD), sehingga secara menyeluruh tingkat pendidikan pada masyarakat Gunungrejo tergolong rendah. Sementara dalam bidang sosial ekonomi, masyarakat Desa Gunungrejo mayoritas berprofesi sebagai petani sawah dan sebagai profesi sampingannya yaitu beternak mulai dari sapi hingga perunggasan. Secara ringkas mata pencaharian masyarakat Desa Gunungrejo ditunjukkan pada gambar 3 .

Berdasarkan gambar 3 tersebut dapat diketahui bahwa dari total penduduk Desa Gunungrejo keseluruhan, persentase profesi terbanyak pada masyarakatnya adalah profesi petani dan peternak, kondisi tersebut berangkat dari keseluruhan luas wilayah Desa Gunungrejo 
Nasrudin, Edhi Martono, Subejo -- Peran Sarjana Membangun Desa (SMD) Dalam Peningkatan Ekonomi Masyarakat Dan Implikasinya Terhadap Ketahanan Ekonomi Masyarakat (Studi Pada Kelompok Peternak Gunungrejo Makmur, Kabupaten Lamongan - Jawa Timur)

Gambar 3

Mata Pencaharian masyarakat Desa Gunungrejo

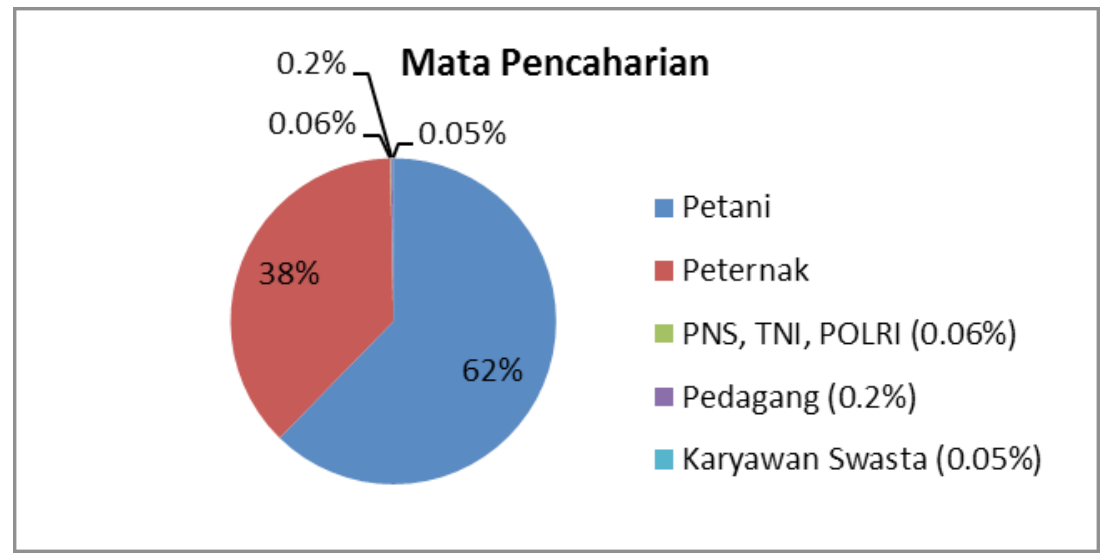

Sumber: Buku Laporan Profil Desa Tahun 2015

selain pemukiman adalah persawahan dan perkebunan sehingga tepat untuk digunakan media tanam padi untuk areal persawahan dan unit usaha peternakan untuk areal perkebunan karena nilai ekonomisnya lebih tinggi hasil usaha peternakan dibandingkan hasil tanaman perkebunan.

\section{Profil Peternakan Gunungrejo Makmur}

Berdasarkan data kondisi sosial ekonomi masyarakat di Desa Gunungrejo sektor peternakan memiliki Produk Domestik Bruto (PDB) terbesar yaitu Rp 9.524.187.000 pada tahun 2015, dimana hal tersebut berarti, area wilayah Desa Gunungrejo memiliki potensi untuk dikembangkannya sektor peternakan mulai dari perunggasan petelur maupun pedaging sampai peternakan sapi potong dan pembibitan. Dari total 1200 peternakan yang ada, hanya 2 (dua) jenis komoditas peternakan yang sudah menggunakan pola beternak untuk orientasi bisnis yaitu peternakan Gunungrejo Makmur I dengan komoditas ayam petelur dan peternakan Gunungrejo Makmur II yang merupakan peternakan pembibitan dan penggemukan sapi.

Dari hasil informasi tersebut, kabar baiknya adalah peternakan Gunungrejo
Makmur merupakan peternakan dengan model peternakan modern dan telah berhasil beberapa kali menjuarai kontes sapi tingkat nasional dan pada tahun 2015 telah berhasil mendapatkan penghargaan Adikarya Pangan Nusantara dari Presiden RI. Sementara untuk komoditas ayam petelur, berkembangnya peternakan ayam ini telah membuat Kecamatan Kedungpring menjadi sentra ayam petelur dan menjadi rujukan dari beberapa daerah untuk membeli telur.

Sebelum adanya peternakan Gunungrejo Makmur terlebih dahulu di tahun 2001 telah dirintis usaha peternakan yang merupakan peternakan ayam petelur dimana saat ini mampu menampung 150.000 ekor ayam petelur dengan anggota kelompok lebih dari 100-an orang. Hingga pada tahun 2008 ketika usaha ayam petelur semakin maju, Drh. Suparto sebagai ketua serta pendamping peternakan Gunungrejo Makmur, telah sukses mendapat dana hibah bersyarat sebesar Rp 365.000.000 dari program Sarjana Membangun Desa (SMD) yang diselenggarakan oleh Ditjen Peternakan, Kementerian Pertanian, akhirnya Drh. Suparto bersama anggota kelompoknya bersepakat untuk mendirikan peternakan sapi 
Gambar 4

Struktur Pengurus Peternak Gunungrejo Makmur

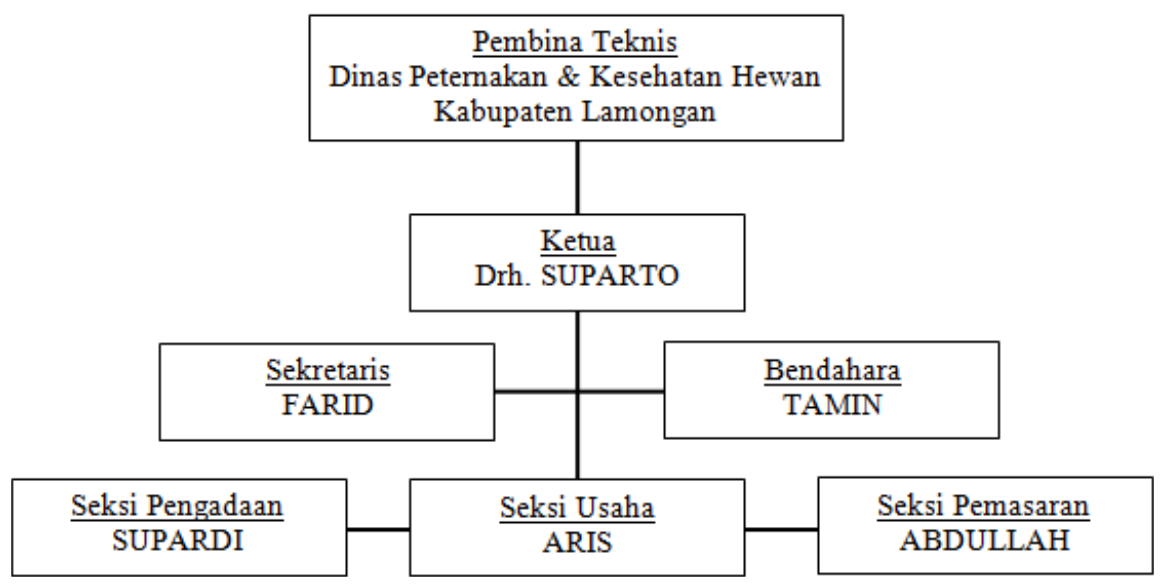

Sumber: Buku Profil Kelompok Peternak Gunungrejo Makmur

potong dengan awal pembelian sebanyak 37 ekor pada tahun 2008, dengan nama Peternakan Gunungrejo Makmur. Adapun struktur organisasi kelompok peternak Gunungrejo Makmur ditunjukkan pada gambar 4.

\section{Peran Sarjana Membangun Desa (SMD)}

Secara umum definisi Sarjana Membangun Desa (SMD) merupakan bentuk kesadaran para pemuda khususnya sarjana yang telah selesai menempuh pendidikan tinggi, kemudian memilih kembali ke daerah, untuk membangun dan mengembangkan potensi lokal di daerahnya bersama masyarakat. Adanya bentuk kesadaran ini diharapkan dengan semakin banyaknya para lulusan sarjana yang ikut berpartisipasi aktif membangun daerahnya, maka akan muncul basis-basis industri lokal maupun UMKM yang dipelopori oleh para pemuda sehingga tercipta kondisi daerah yang kuat secara perekonomian serta masyarakat yang memiliki pemahaman teknologi informasi yang berdaya saing

Adapun definisi peran adalah segala tindakan yang dilakukan oleh seseorang atau lembaga yang mempunyai kedudukan tertentu dalam masyarakat dalam melaksanakan hak dan kewajiban yang dimilikinya sesuai dengan kedudukan dan fungsinya (Zulkarnain, 2015). Peran SMD pada peternakan Gunungrejo Makmur telah banyak dirasakan terutama terhadap masyarakat yang tergabung dalam kelompok peternak tersebut. Adapun peran dari SMD dapat ditunjukkan di bawah ini.

Partama, sebagai pelopor berdirinya peternakan baik komoditas ayam petelur maupun sapi potong, karena sejak tahun 2001 Drh Suparto telah lebih dulu mengawali beternak ayam petelur karena melihat potensi bahwa di Kabupaten Lamongan belum ada sentra peternakan ayam petelur dan hasil pertanian untuk pakan ternak sangat melimpah.

Kedua, sebagai pendamping kelompok peternak. Ini berjalan selama 5 tahun, selanjutnya Drh Suparto selaku SMD dipercaya masyarakat untuk menjadi ketua kelompok Gunungrejo Makmur untuk periode 2013 hingga sekarang baik komoditas ayam petelur maupun sapi potong.

Ketiga, sebagai innovator dari pertanian konvensional menjadi peternakan berorientasi bisnis, artinya sebelum adanya peternakan 
Nasrudin, Edhi Martono, Subejo -- Peran Sarjana Membangun Desa (SMD) Dalam Peningkatan Ekonomi Masyarakat Dan Implikasinya Terhadap Ketahanan Ekonomi Masyarakat (Studi Pada Kelompok Peternak Gunungrejo Makmur, Kabupaten Lamongan - Jawa Timur)

Gunungrejo Makmur yang diprakarsai oleh Drh Suparto, mayoritas masyarakat berprofesi sebagai petani dengan tingkat keuntungan sekali panen rata-rata 1 juta, akan tetapi setelah peternakan Gunungrejo Makmur berdiri kondisi kesejahteraan masyarakat menjadi meningkat karena profit yang didapat dari hasil beternak cukup tinggi yaitu 2,2 juta per bulan dari beternak sapi dan 250 ribu per hari dari beternak ayam petelur per seribu ekor.

Keempat, sebagai pendamping akses permodalan, di sini dapat dilihat rentang antara 2008 hingga saat ini cukup banyak modal usaha yang masuk untuk pengembangan usaha seperti dana hibah program SMD sebesar 365 juta di tahun 2008, Kredit KUPS (Kredit Usaha Peternakan Sapi) dari Bank Jatim 750 juta di tahun 2009, KKPE (Kredit Ketahanan Pangan dan Ekonmi) Bank Jatim 1,5 Miliar tahun 2013, serta membantu masyarakat mendapat akses KUR (Kredit Usaha Rakyat) BRI untuk pengembangan komoditas ayam petelur secara personal. Kelima, perannya yaitu pengembang jaringan kemitraan dan pemasaran, khususnya untuk komoditas sapi potong peranan Drh Suparto telah mampu memutus rantai pemasaran yang cukup panjang dengan cara memasarkan hasil ternak langsung kepada RPH (Rumah Potong Hewan) untuk menadapat harga yang kompetitif, serta saat ini peternakan Gunungrejo Makmur telah bermitra dengan PT. Semen Gresik sebagai pengelola dana CSR (Corporate Social Responsibility).

\section{Parameter Keberhasilan SMD Terhadap Peningkatan Ekonomi Masyarakat}

Parameter keberhasilan peran SMD dapat dilihat dari tiga aspek yaitu aspek teknis, aspek ekonomis, aspek kelembagaan (Direktorat Jendral Peternakan dan Kedokteran Hewan,
2011), lebih lanjut parameter yang dikaji adalah keberhasilan peran SMD terhadap peningkatan ekonomi masyarakat sehingga aspek-aspek yang digunakan adalah penjabaran dari ketiga aspek di atas.

Pertama, aspek sumberdaya manusia. Keberadaan sumberdaya manusia yang produktif dan berkualitas merupakan faktor utama penggerak ekonomi dalam pembangunan. Pembangunan yang berhasil adalah pembangunan yang mampu melihat manusia sebagai modal pembangunan maupun komponen pembangunan. Parameter keberhasilan pada aspek sumberdaya manusia khususnya pada masyarakat Gunungrejo adalah tersedianya SDM yang produktif di masyarakat. Hasil temuan di lapangan ketersediaan sumberdaya manusia pada peternakan Gunungrejo Makmur cukup melimpah kondisi ini didasarkan pada masih tingginya jumlah SDM produktif di masyarakat yang didasarkan pada usia produktif 1560 tahun, serta masih tingginya kesadaran masyarakat untuk ikut beternak.

Kedua, aspek motivasi. Dalam setiap usaha untuk mencapai tujuan, setiap orang akan memiliki motivasi tersendiri sebagai dasar acuan dalam melakukan berbagai kegiatan, menurut Bernson dan Skinner (Marjono, 2007) mengemukakan bahwa motivasi merupakan dorongan kerja yang timbul dari diri seseorang untuk berperilaku dalam mencapai tujuan yang telah di tentukan. Berdasarkan dua definisi motivasi di atas, pada aspek motivasi berikut ini peneliti membaginya dalam dua aspek yaitu motivasi pemimpin itu sendiri dan motivasi anggota kelompok, pembagian motivasi tersebut didasarkan pada keadaan dimana umumnya seorang pemimpin akan memiliki motivasi yang lebih kuat karena dalam banyak kesempatan digunakan untuk 
memikirkan perkembangan usaha yang telah dibangun bersama anggotanya.

Lebih lanjut Adapun E. J. Donald (dalam Komaruddin, 1983) membagi motivasi dalam dua jenis, yang pertama adalah motivasi intrinsik yaitu motivasi yang timbul dari dalam diri seseorang, sifat motivasi ini lebih cenderung berasal dari kesadaran dalam diri seseorang dalam melihat kondisi sekitarnya, yang kedua adalah motivasi ekstrinsik yaitu motivasi yang datang dari luar diri sendiri misalnya pilihan faktor ekonomi yang lebih baik dan lain sebagainya. Hasil temuan di lapangan didapat bahwa, motivasi pemimpin disarkan atas dasar kesadaran berwirausaha dan membantu masyarakat (intrinsik), sedangkan anggota atas dasar kebutuhan ekononomi (ekstrinsik).

Ketiga, aspek kepemimpinan. Kualitas kepemimpinan yang baik akan melahirkan budaya kerja dan kerjasama tim yang baik pula untuk mencapai tujuan organisasi. Secara umum kepemimpinan dapat digambarkan sebagai proses sosial yang mempengaruhi tujuan kelompok, motif individu, kemampuan anggota kelompok dan interpretasi dari kegiatan internal maupun eksternal. Menurut Robbins dan Judge (2015) kepemimpinan adalah kemampuan untuk mempengaruhi kelompok terhadap pencapaian dari visi atau sekumpulan tujuan.

Hasil temuan menunjukkan bahwa aspek kepemimpinan dalam hal ini adalah Drh Suparto telah mencapai kepemimpinan teladan yang mampu membawa perubahan khususnya pada kelompok peternak Gunungrejo Makmur, baik untuk komoditas sapi potong maupun ayam petelur, tak hanya itu baru-baru ini lewat gagasan dari ketua kelompok, kelompok peternak Gunungrejo Makmur telah berhasil menginisiasi berdirinya Koperasi Gunungrejo Makmur yang tujuannya untuk memberikan pinjaman atau akses suplai pakan ternak yang dapat dibayar ketika ternaknya panen dan memberikan pinjaman kepada anggota maupun masyarakat desa yang ingin mendirikan dan

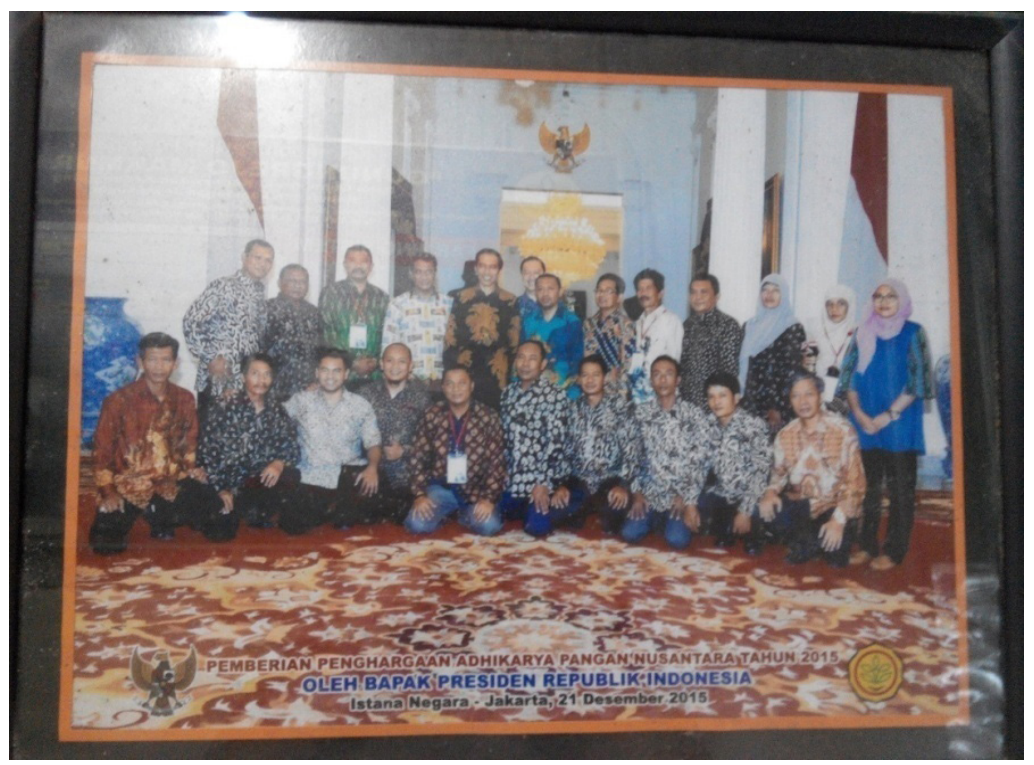

Sumber: Dokumentasi 2017 
Nasrudin, Edhi Martono, Subejo -- Peran Sarjana Membangun Desa (SMD) Dalam Peningkatan Ekonomi Masyarakat Dan Implikasinya Terhadap Ketahanan Ekonomi Masyarakat (Studi Pada Kelompok Peternak Gunungrejo Makmur, Kabupaten Lamongan - Jawa Timur)

mengembangkan usaha peternakannya. Hal ini senada dengan peparan Subekti (2016:161) yang menjelaskan bahwa potensi adanya koperasi untuk meningkatkan kesejahteraan anggotanya memberikan kontribusi terhadap ketahanan ekonomi masyarakat. Sementara di tahun 2015 Drh Suparto beserta kelompoknya telah berhasil mendapat penghargaan dari Presiden RI, karena telah memenangkan kontes sapi nasional (lihat gambar 5).

Keempat, aspek manajemen. Fungsi manajemen menurut Terry dan Leslie (2010) dapat dibagi menjadi empat bagian yaitu planning (perencanaan), organizing (pengorganisasian), actuating (pelaksanaan), dan controlling (pengawasan). Pada aspek manajemen temuan di lapangan pada peternakan Gunungrejo Makmur dalam perjalanannya telah mengalami banyak evaluasi dan perbaikan, karena pada dasarnya peternakan sapi yang dibangun bersama tersebut masih tergolong peternakan pemula, pada awal kelompok peternak Gunungrejo Makmur mendapatkan bantuan modal dari program Sarjana Membangun Desa (SMD) sistem manajemen pembagian tugas kelompok penggemukan sapi potong masih berbentuk sederhana yaitu penanganan pemeliharaan sapi dibagi per personal artinya satu orang menangani satu sapi. Akan tetapi hasil evaluasi tiga bulan pertama menunjukkan hasil yang kurang maksimal dikarenakan karakter manusia yang berbeda-beda ada yang rajin ada yang kurang rajin. Selanjutnya sistem menejemen berkembang menjadi sistem mingguan akan tetapi sistem ini pun juga memiliki kekurangan yaitu dalam beberapa kasus sebagian kelompok peternak meninggalkan tanggung jawab karena ada kesibukan lain, dan untuk saat ini sistem menajemen yang profesional telah berhasil dibentuk yaitu sistem manajemen yang terstruktur dan terbagi dalam masing-masing bidang serta mengambil karyawan dari luar khusus untuk bagian kandang.

Kelima, aspek ketersediaan modal. Modal dalam hal ini adalah modal finansial merupakan hal yang sangat penting terutama ketika akan mendirikan suatu usaha, karena memang tanpa uang sebuah usaha tidak akan bisa berjalan. Namun dalam usaha seringkali para pemilik usaha menghadapi masalah dalam penyediaan modal. Dalam beberapa literatur modal finansial seringkali disebut sebagai faktor utama yang menghambat perkembangan usaha. Menurut Tambunan (2002:74) terdapat dua permasalahan yang masih sering dihadapi oleh pelaku usaha di Indonesia yaitu penyediaan modal awal dan ketersediaan finansial jangka panjang yang sangat diperlukan untuk pertumbuhan output dalam waktu jangka panjang.

Parameter keberhasilan SMD pada aspek modal ialah tersedianya modal untuk pengembangan usaha, temuan di lapangan didapat bahwa untuk komoditas sapi potong ketersediaan modal cukup baik karena sering mendapat dukungan dari pemerintah berupa kredit perbankan dan investasi perorangan bahkan dana hibah seperti program SMD. Sementara untuk ayam petelur ketersediaan modal cukup dari sumber pribadi ditambah kredit dari perbankan seperti KUR BRI.

Keenam, aspek legalitas. Aspek hukum dan legalitas merupakan landasan awal dalam menjalankan sebuah usaha, hukum dasar yang mengatur tentang perizinan usaha peternakan telah ditetapkan dalam Keputusan Bupati Nomor 42 Tahun 2002 Tentang Izin Usaha Peternakan. Pentingnya pemenuhan aspek hukum juga disampaikan oleh Syarbini dan Priyono (2014) yang mengemukakan aspek 
hukum merupakan pondasi menuju perusahaan yang kuat, dengan begitu sebaiknya dipatuhi bukan dihindari, agar usaha yang dijalankan tidak bermasalah di kemudian hari. Parameter keberhasilan untuk aspek legalitas ialah terpenuhinya surat Izin usaha. Hasil temuan di lapangan pada peternakan Gunungrejo Makmur menunjukkan sampai saat ini aspek legalitas masih sebatas SK pendirian yang dikeluarkan KEMENHUMHAM, dan dalam perjalanannya tidak begitu banyak masalah untuk kaitannya dengan pembayaran pajak, pengajuan dana hibah dan kredit perbankan.

Ketujuh, aspek ekonomi. Tujuan utama dalam berwirausaha adalah usaha yang dijalankan mendapatkan keuntungan, terlebih sektor wirausaha tersebut memiliki manfaat bagi masyarakat maupun lingkungan sekitar, pada kelompok peternak Gunungrejo Makmur sendiri tujuan dibentuk kelompok tani ternak adalah agar terbentuk kesadaran kolektif untuk bersama-sama membuka usaha peternakan, dimana tujuan akhirnya adalah tiap-tiap anggota dapat merasakan hasil dari usaha peternakan yang dijalankan secara bersama-sama.
Adapun parameter utama keberhasilan SMD dalam peningkatan ekonomi ialah usaha peternakan Gunungrejo Makmur baik untuk sapi potong maupun ayam petelur hasilnya mampu menjadi sumber utama pendapatan dari hasil beternak. Temuan di lapangan didapatkan hasil yang cukup baik yaitu terjadi peningkatan ekonomi pada masyarakat, misalnya untuk peternakan sapi potong mampu menghasilkan 2,2 juta/ bulan/ anggota, dan untuk peternakan ayam petelur mampu menghasilkan $250 \mathrm{ribu} / \mathrm{hari} /$ orang untuk kapasitas 1000 ekor (lihat gambar 6).

Kedelapan, aspek perubahan pasar. Pada setiap sektor usaha dinamika perubahan pasar akan selalu menjadi perhatian khusus karena hal ini sangat berkenaan dengan tingkat margin profit yang akan didapat, terlebih pada sektor peternakan naik turunnya harga jual komoditas hasil ternak di pasaran akan sangat menentukan para peternak merugi atau mendapat untung. Perubahan pasar menurut Bangun (2010:31) adalah kondisi dimana terjadi ketidakstabilan harga atau ketidakseimbangan antara tingkat penawaran dan permintaan karena beberapa

Gambar 6

Peternakan Gunungrejo Makmur (Sapi Potong)

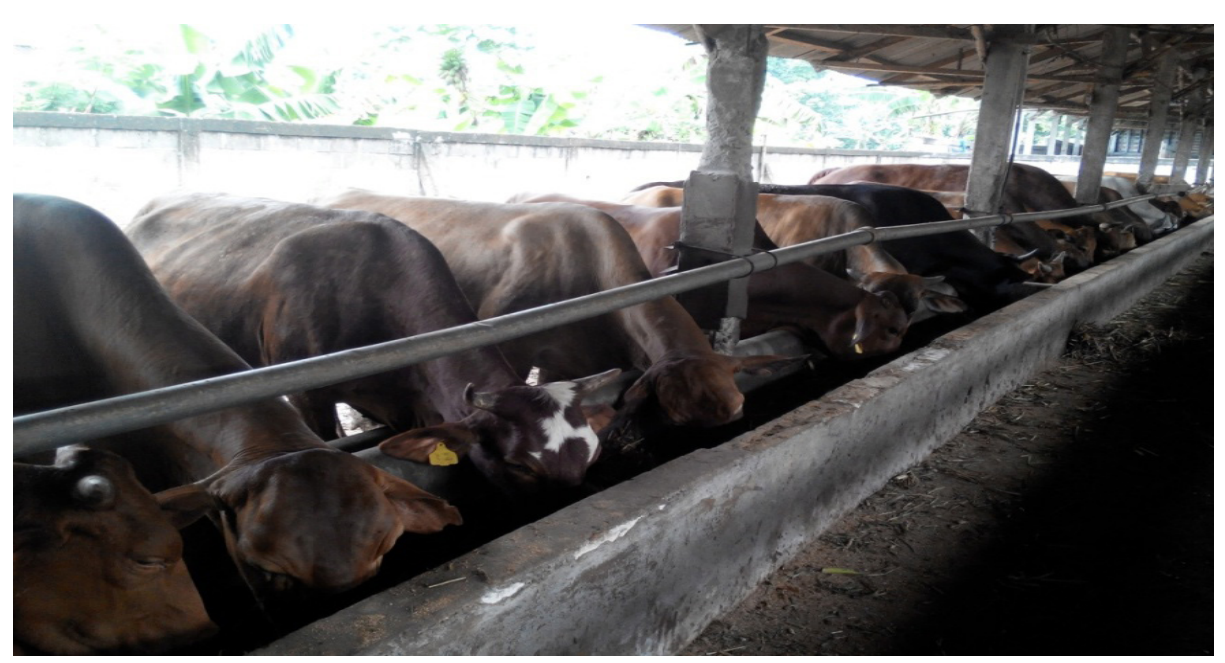

Sumber: Dokumentasi peneliti, 2017 
Nasrudin, Edhi Martono, Subejo -- Peran Sarjana Membangun Desa (SMD) Dalam Peningkatan Ekonomi Masyarakat Dan Implikasinya Terhadap Ketahanan Ekonomi Masyarakat (Studi Pada Kelompok Peternak Gunungrejo Makmur, Kabupaten Lamongan - Jawa Timur)

faktor yaitu teknologi yang digunakan, tingkat pendapatan masyarakat, pajak serta subsidi dari pemerintah.

Adapun parameter keberhasilan peran SMD dalam menghadapi perubahan pasar yang dinamis ialah mampu mengantisipasi perubahan pasar, baik dengan cara menjual hasil ternak kepada konsumen akhir atau menunda penjualan hasil ternak dengan harapan di waktu mendatang terjadi peningkatan harga jual. Hasil temuan di lapangan pada peternakan Gunungrejo Makmur didapatkan kesimpulan, perubahan pasar merupakan aspek eksternal sehingga langkah antisipasi yang diambil para peternak lebih kepada meminimalkan kerugian, seperti menunda penjualan atau penghematan pakan.

Kesembilan, aspek pemasaran. Dalam sistem penjualan, strategi untuk dapat memaksimalkan margin keuntungan adalah dengan menjual langsung kepada konsumen akhir, karena dengan menjual kepada konsumen akhir secara tidak langsung penjualan telah melewati pengepul, agen dan seterusnya, sehingga proses pemasaran akan berjalan lebih efektif. Hasil temuan di lapangan pada peternakan Gunungrejo Makmur aspek pemasaran penjualan sapi potong telah dipercaya menyuplai RPH (Rumah Potong Hewan) di beberapa daerah, untuk penjualan telur ayam dapat langsung dijual di pasar secara eceran atau sistem partai untuk menyuplai luar daerah.

Kesepuluh, aspek pengembangan dan keberlanjutan usaha. Ada beberapa perbedaan dalam definisi pengembangan dan keberlanjutan usaha, yang dimaksud dengan pengembangan dalam kaitannya dengan peternakan Gunungrejo Makmur adalah lebih kepada peningkatan kapasitas ternak maupun sistem peternakan yang lebih terpadu, sementara yang dimaksud dengan keberlanjutan usaha adalah fokus pembicaraan tentang stabilitas usaha yang dimiliki sehingga dari usaha tersebut pada akhirnya akan dipilih untuk dilanjutkan ataukah berhenti.

Adapun parameter keberhasilan yang digunakan untuk pengembangan dan keberlanjutan usaha ialah terjadi peningkatan kapasitas ternak dan tercapainya stabilitas usaha. Untuk hasil temuan dilapangan pada peternakan Gunungrejo Makmur didapat kondisi dimana terjadi perkembangan yang cukup pesat untuk komoditas ayam petelur, sementara untuk komoditas sapi potong lebih memilih bertahan dengan jumlah penjualan 250 ekor/tahun (lihat gambar 7)/

\section{Kendala Yang Ada}

Pada dunia peternakan, kendala terhadap jalannya kelompok peternak atau pencapaian yang tidak sesuai target masih sering kali terjadi, belum lagi faktor eksternal menghadapi kondisi pasar yang selalu dinamis seperti misalnya harga-harga yang fluktuatif membuat para kelompok peternak harus berfikir ekstra untuk menyiasati kondisi tersebut, karenanya para peternak harus berlomba antara penghematan pengeluaran pakan untuk operasional ternak dan selisih omzet dengan profit yang tipis ketika harga pasar sedang jatuh. Dalam perjalanannya, peran SMD pada peternakan Gunungrejo Makmur menghadapi dua kendala sebagai berikut.

Pertama, kendala harga tidak stabil. Parameter utama untuk kendala harga yang tidak stabil yaitu semakin menurunnya harga jual untuk komoditas hasil ternak. Untuk komoditas sapi potong kendala yang terjadi adalah masih kecilnya tingkat profit yaitu hasil penjualan $2-2,5 \%$, kecilnya profit atau tidak 
Gambar 7

Peternakan Gunungrejo Makmur (Ayam Petelur)

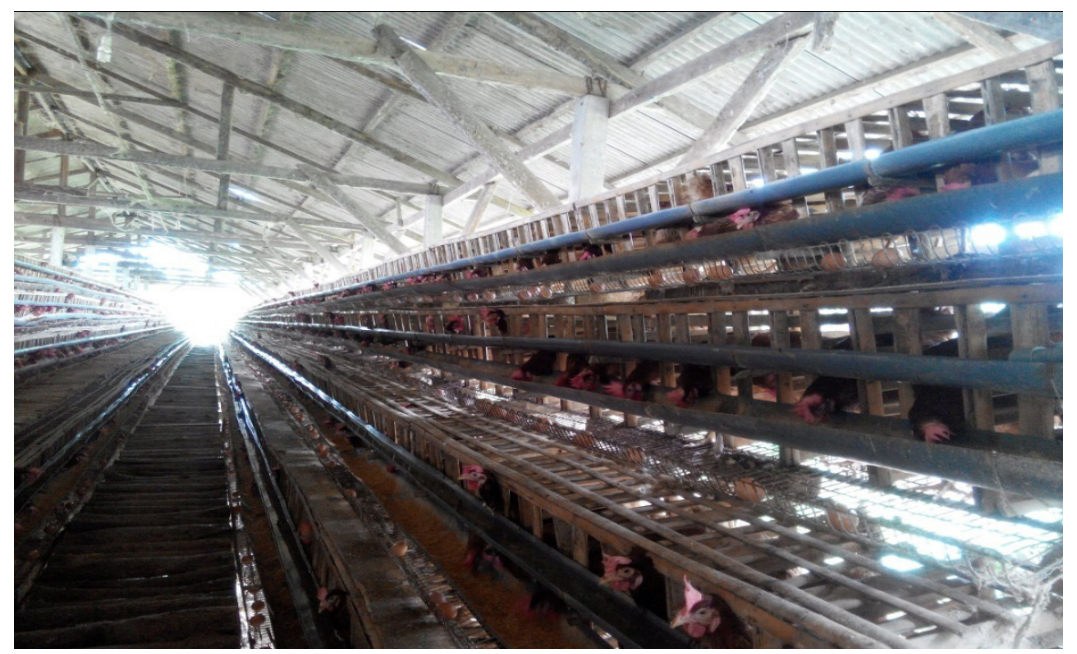

Sumber: Dokumentasi Peneliti, 2017

stabilnya harga di pasaran merupakan dampak dari kebijakan pemerintah yang lebih memilih kebijakan impor daging sebagai penanggulanan kekurangan suplai daging dalam negeri daripada memberdayakan peternak lokal untuk mengupayakan pemenuhan kebutuhan daging nasional.

Sampai saat ini ketergantungan impor daging di Indonesia terhadap negara lain masih cukup besar yakni 35\% atau sekitar135,1 ribu ton dari kebutuhan 385 ribu ton per tahun dari total konsumsi daging nasional (Jiuhardi, 2016:78). Kendala dari harga yang tidak stabil selanjutnya adalah telah disahkannya UU No. 18 tahun 2009 tentang Peternakan dan Kesehatan Hewan, dimana isinya adalah memberi izin perusahaan integrasi untuk beternak ayam petelur secara besar-besaran yang berpotensi menggeser peternak lokal.

Kedua, kendala pengembangan. Kendala pengembangan pada peternakan Gunungrejo Makmur khususnya untuk komoditas sapi potong adalah sistem pembibitan sapi potong di Indonesia yang masih mengandalkan suplai dari petani, hal ini senada dengan pernyataan Prima (Jiuhardi, 2016:79) yang mengatakan bahwa kekurangan pasokan sapi di Indonesia disebabkan sistem pembibitan sapi potong nasional yang masih parsial sehingga tidak menjamin kesinambungan, padahal titik kritis dalam pengembangan sapi potong di Indonesia adalah pembibitan.

Artinya selama ini penyediaan bibit sapi potong di Indonesia masih konvensional dengan mengandalkan suplai dari petani sehingga harganya lebih mahal, yaitu untuk bibit sapi umur 2-3 tahun harganya 17 juta, dan harga jual setelah proses peggemukan selama 3-4 bulan adalah 21 juta dimana harga ini belum terpotong biaya pakan ternak, kondisi ini yang membuat para peternak sapi potong di Indonesia mendapat profit yang relatif kecil sehingga berdampak pada melambatnya pengembangan peternakan di Indonesia. Di sisi lain harga daging sapi di Indonesia masih kalah dengan harga daging impor.

\section{Implikasinya Ketahanan Ekonomi Masyarakat}

Pada implikasi peran SMD terhadap ketahanan ekonomi masyarakat, parameter keberhasilan yang digunakan yakni 
Nasrudin, Edhi Martono, Subejo -- Peran Sarjana Membangun Desa (SMD) Dalam Peningkatan Ekonomi Masyarakat Dan Implikasinya Terhadap Ketahanan Ekonomi Masyarakat (Studi Pada Kelompok Peternak Gunungrejo Makmur, Kabupaten Lamongan - Jawa Timur)

menggunakan dua pendekatan, yaitu pendekatan internal ketahanan keluarga yaitu pendekatan pendapatan dan kebutuhan, serta pendekatan usaha peternakan itu sendiri terdiri dari pendekatan internal usaha yaitu pendekataan kemandirian dan stabilitas usaha dan pendekatan eksternal usaha yaitu pendekatan saat terjadi krisis. Adapun detail dari empat pendekatan tersebut adalah sebagai berikut.

Pertama, pendekatan pendapatan. Definisi pendapatan menurut Reksoprayitno (2004:79) adalah jumlah penghasilan yang diterima oleh para anggota masyarakat untuk jangka waktu tertentu sebagai balas jasa atau faktor-faktor produksi yang telah disumbangkan. Pada penelitian ini ukuran yang digunakan sebagai parameter pendapatan adalah besaran UMK (Upah Minimum Kabupaten/Kota) di tingkat kabupaten, serta adanya perubahan pendapatan dari sebelum adanya Program Sarjana Membangun Desa (SMD). Standar kemiskinan menurut Basia (2016:54) yaitu seseorang dapat dikategorikan miskin jika diukur dari pendapatan yang diperoleh kurang atau masih di bawah standar dari UMK yang ditetapkan oleh pemerintah setempat, sedangkan kategori tidak miskin jika pendapatan lebih dari UMK yang sudah ditetapkan.

Hasil penelitian menunjukkan bahwa tingkat pendapatan masyarakat lebih banyak berasal dari hasil beternak, dalam hal ini adalah keuntungan dari beternak ayam petelur dan sapi potong. Maka dari sudut pandang aspek pendapatan dapat dikatakan bahwa masyarakat Desa Gunungrejo yang tergabung dalam kelompok peternakan Gunungrejo Makmur telah mencapai ketahanan ekonomi dari aspek peningkatan pendapatan. Hal tersebut didasarkan pada perubahan peningkatan pendapatan yang signifikan setelah menjalankan program SMD dan pendapatan masyarakat Desa Gunungrejo telah melebihi UMK per-bulan untuk Kabupaten Lamongan. Oleh karena itu demikian dapat disimpulkan bahwa peran Sarjana Membangun Desa (SMD) pada peternakan Gunungrejo Makmur telah berimplikasi pada ketahanan ekonomi masyarakat jika ditinjau dari aspek pendekatan pendapatan.

Kedua, pendekatan kebutuhan. Pengukuran pendekatan kebutuhan untuk para peternak Gunungrejo Makmur dalam pemenuhan kebutuhan ekonomi didasarkan pada tingkat penghasilan yang didapat dari usaha beternak. Hal tersebut juga berdasar konsep BPS (Badan Pusat Statistik) yang menggunakan pendekatan kemampuan untuk memenuhi kebutuhan dasar (basic need approach). Pendekatan pada konsep ini memandang bahwa kemiskinan merupakan kondisi ketidakmampuan dari sisi ekonomi untuk memenuhi kebutuhan dasar seperti makanan, dengan kata lain kemiskinan dapat diartikan sebagai ketidakmampuan suatu keluarga dari sisi ekonomi dalam memenuhi kebutuhan akan makanan maupun non makanan yang bersifat primer.

Hasil penelitian menemukan kondisi bahwa hasil dari kegiatan beternak sapi potong maupun ayam petelur pada masyarakat Desa Gunungrejo telah cukup untuk memenuhi kebutuhan sehari-hari seperti sandang, papan dan pangan serta untuk biaya pendidikan anak-anaknya. Hal tersebut didasarkan pada tingkat pendapatan dari usaha beternak yang meningkat jauh melampaui UMK di kabupaten setempat, sehingga secara tidak langsung masyarakat tersebut dapat dikatakan sebagai masyarakat yang berkecukupan secara ekonomi serta kondisi tersebut akan akan terus 
stabil selama tidak ada perubahan pasar yang cukup signifikan atau kebijakan pemerintah yang menyebabkan para peternak sapi potong maupun ayam petelur harus berhenti dari kegiatan beternak.

Ketiga, pendekatan kemandirian dan stabilitas usaha. Dalam dunia wirausaha peternakan yang berorientasi bisnis, istilah kemandirian usaha memiliki arti sebuah sikap dan kebijakan organisasi atau kelompok peternak untuk bebas dalam bertindak, dimana keberlangsungan usahanya tidak bergantung pada ada atau tidaknya dukungan modal dari pemerintah, serta mampu survive saat kondisi pasar mulai tidak stabil. Lebih lanjut menurut pandangan Lerner (1976:67) konsep kemandirian (autonomy) mencakup kebebasan untuk bertindak, tidak bergantung kepada orang lain, tidak bergantung pada ada atau tidaknya dukungan dari pemerintah, tidak terpengaruh kondisi lingkungan serta bebas mengatur kebutuhan sendiri. Sementara apa yang dimaksud dengan stabilitas usaha adalah kondisi dimana suatu unit usaha yang mampu bertahan saat terjadi krisis dan tetap survive menjaga keberlangsungan usaha yang dijalankan, lebih lanjut stabilitas usaha jika dikaitkan dengan peningkatan ketahanan ekonomi masyarakat yaitu profit dari hasil usaha tersebut secara kontinyu mampu memberikan dan mencukupi kebutuhan keluarga serta memiliki dampak yang positif bagi masyarakat sekitar.

Temuan di lapangan menunjukkan tingkat kemandirian dan stabilitas usaha pada peternakan Gunungrejo Makmur maupun masyarakat yang berada di bawah binaan Gunungrejo Makmur, memiliki tingkat kemandirian dan stabilitas usaha yang cukup baik, terutama untuk komoditas ayam petelur dimana dalam perjalanannya walaupun minim ada dukungan dari pemerintah, perkembangan komoditas ayam petelur terjadi cukup pesat, banyak masyarakat secara mandiri mampu mendirikan peternakan ayam petelur yang diikuti dalam daerah maupun luar daerah seperti Tuban dan Bojonegoro. Sementara tingkat stabilitas usaha untuk komoditas sapi potong dapat dilihat dari perkembangan kapasitas sapi potong yang cukup pesat dari tahun ke tahun, walaupun nilai ekonomis dari beternak sapi tidak cukup baik daripada komoditas ayam petelur, akan tetapi pada nyatanya hingga saat ini keberadaan usaha sapi potong Gunungrejo Makmur masih tetap terjaga. Ini terbukti dari kelompok yang masih mampu menjual sapi potong sebanyak 250 ekor per tahunnya.

Keempat, pendekatan saat terjadi krisis. Salah satu kendala utama yang masih sering dialami oleh para peternak khususnya peternakan Gunungrejo Makmur adalah faktor pasar yang kurang stabil, satu hal yang perlu dipahami dari faktor pasar adalah faktor eksternal dari peternakan itu sendiri sehingga pemecahan masalah yang paling utama juga dari eksternal yaitu kebijakan dari pemerintah baik daerah maupun pusat, sementara pengambilan solusi dari para peternak sifatnya lebih kepada mengantisipasi atau meminimalisasi kerugian.

Temuan di lapangan terutama dalam penanganan saat terjadi krisis baik untuk komoditas sapi potong maupun ayam petelur yaitu melakukan beberapa antisipasi untuk menghadapi kondisi pasar yang kurang stabil. Untuk komoditas sapi potong langkah yang diterapkan adalah menjual kepada Rumah Potong Hewan (RPH) yang memiliki tingkat harga yang kompetitif, atau menunda penjualan dengan harapan untuk bulan-bulan 
Nasrudin, Edhi Martono, Subejo -- Peran Sarjana Membangun Desa (SMD) Dalam Peningkatan Ekonomi Masyarakat Dan Implikasinya Terhadap Ketahanan Ekonomi Masyarakat (Studi Pada Kelompok Peternak Gunungrejo Makmur, Kabupaten Lamongan - Jawa Timur)

berikutnya harga daging di pasaran akan kembali normal. Untuk komoditas ayam petelur sendiri langkah yang diambil saat kondisi pasar kurang stabil atau kondisi dimana nilai jual telur di pasaran mengalami penurunan harga, yaitu dengan mengurangi jumlah pakan harian dengan tujuan untuk lebih menghemat biaya pemeliharaan.

\section{SIMPULAN}

Berdasar pembahasan di atas maka dapat ditarik simpulan sebagai berikut.

Pertama, peran SMD pada kelompok peternak Gunungrejo Makmur telah berhasil dalam pemberdayaan dan peningkatan ekonomi masyarakat, hal ini terbukti dari data perkembangan penjualan sapi potong yang meningkat setiap tahunnya dan puncaknya pada tahun 2014 dimana total penjualan sapi potong sudah mencapai 409 ekor. Pada perkembangannya, lebih dipilihnya komoditas ayam petelur sebagai komoditas utama untuk meningkatkan nilai ekonomi masyarakat dikarenakan hasil dari komoditas ayam petelur memiliki nilai ekonomi yang lebih tinggi daripada menjadi buruh tani maupun beternak sapi potong.

Kedua, kendala pada peternakan Gunungrejo Makmur baik komoditas ayam petelur maupun sapi potong lebih banyak berasal dari faktor eksternal seperti kondisi pasar yang fluktuatif, akan tetapi kondisi ini tidak sampai mempengaruhi stabilitas usaha peternakan Gunungrejo Makmur atau membuat masyarakat sampai berhenti berwirausaha di sektor peternakan. Kendala eksternal selanjutnya adalah masih buruknya sistem penyediaan bibit sapi potong di Indonesia, hal ini dapat dilihat dari masih tingginya harga bibit sapi di pasaran, karena selama ini para peternak hanya mendapat pasokan bibit sapi dari para petani setempat, di sisi lain kondisi tersebut disebabkan karena belum adanya program dari pemerintah dengan tujuan untuk menyelesaikan permasalahan tingginya harga bibit sapi.

Ketiga, dalam implikasinya, peran SMD terhadap peningkatan ketahanan ekonomi masyarakat, kelompok ternak Gunungrejo Makmur telah berhasil mencapai tingkat ketahanan ekonomi yang cukup baik, kondisi ini didasarkan pada (1). Untuk pendekatan pendapatan dan kebutuhan, hasil dari beternak sapi potong maupun ayam petelur telah cukup untuk memenuhi kebutuhan sehari hari, terutama untuk sandang, papan, pangan dan pendidikan, serta hasil beternak keuntungannya jauh lebih besar daripada nilai UMK di kabupaten setempat. (2). Untuk pendekatan kemandirian dan stabilitas usaha komoditas peternakan ayam petelur memiliki tingkat kemandirian stabilitas usaha yang cukup baik, hal ini dapat dilihat dari perkembangan peternakan ayam petelur yang cukup pesat walaupun minim dukungan dana dari pemerintah, untuk komoditas sapi potong stabilitas usaha dapat dilihat dari meningkatnya penjualan sapi potong tiap tahunnya. (3). Untuk pendekatan saat terjadi krisis para peternak telah mampu mengantisipasi kondisi pasar yang fluktuatif sehingga saat kondisi harga jual hasil ternak turun atau saat meningkatnya harga pakan ternak, langkah yang diambil peternak telah mampu untuk meminimalisasi kerugian.

\section{DAFTAR PUSTAKA}

Badan Pusat Statistik, 2016, Tingkat Pengangguran di Indonesia, Jakarta: Badan Pusat Statistik.

Bangun, Wilson, 2010, Teori Ekonomi Mikro, Bandung: PT. Refika Aditama. 
Bank Dunia, 2016, Ketimpangan yang semakin lebar, Kantor Bank Dunia: Jakarta.

Basia, Lusmino, 2016, "Strategi Pengembangan Wirausaha Pemuda Dalam Mewujudkan Wirausahawan Mandiri dan Implikasinya Terhadap Ketahanan Ekonomi Keluarga (Studi Pada Koperasi Sumekar di Kampung Sanggrahan Pathuk Kecamatan Ngampilan Kota Yogyakarta, Daerah Istimewa Yogyakarta)", Jurnal

Ketahanan Nasional, Vol.22 No.1.

Davidson, Kenneth M., 2005,"Creating Effective Competition Institutions: Ideas for Transitional Economies", AsianPacific Law and Policy Journal., Vol. 6, hal: 71-129.

Direktorat Jendral Peternakan, 2007, Petunjuk Pelaksanaan Program Sarjana Membangun Desa, Jakarta: Departemen Pertanian.

, 2011, Petunjuk Pelaksanaan Program Sarjana Membangun Desa, Jakarta: Departemen Pertanian.

Jaygree, David, 2008, “The Role of ASEAN Economic Community as a Commitment to Policy Certainty", ASEAN Economic Bulletin, Vol 25, No.2.

Jiuhardi, 2016, “Kajian Tentang Impor Daging di Indonesia", Forum Ekononi, Universitas Mulawarman, vol. 17, no 2.

Komaruddin, 1983, Menejemen Kualitas Pelayanan Terpadu, Jakarta: Rajawali Press.

Lerner, RM., 1976, Concept and Theories of Human Development, Philippines: Addison Wesley.

Marjono, 2007, Pengaruh Kedisiplinan, Motivasi dan Fasilitas Sekolah terhadap prestasi belajar siswa VIII SMPN 8
Purworejo, Tesis: Universitas Jendral Soedirman.

Miyamoto, Michiko, 2015, Tren Ketenagakerjaan dan social di Indonesia tahun 2014-2015: Memperkuat daya saing dan produktivitas melalui pekerjaan layak, Jakarta : Kantor Perburuhan Internasional (ILO).

Morgenthau, Hans J., 2010, Politik Antar Bangsa, Jakarta: Yayasan Pustaka Obor Indonesia.

Prasetyo, Febri A., 2013, Partisipasi Pelaksanaan Program Sarjana Membangun Desa dalam Pengembangan Sapi Potong di Kabupaten Bantul-Daerah Istimewa Yogyakarta, Tesis: Universitas Gadjah Mada.

Reksoprayitno, 2004, Sistem Ekonomi dan Demokrasi Ekonomi, Jakarta: Bina Grafika.

Robbins, Stephen P. dan Timothy A. Judge, 2015. Organizational Behavior. Edisi keenambelas, England: Pearson Education Limited.

Schwab, Klaus, 2016, The Global Competitiveness Report 2016-2017, Geneva: World Economic Forum.

Shofa, Abd Mu'id Aris, 2016, "Peran Pemuda Dalam Pendampingan Mahasiswa dan Implikasinya Terhadap Ketahanan Pribadi (Studi di Pusat Layanan Difabel (PLD) UIN Sunan Kalijaga Yogyakarta”, Jurnal Ketahanan Nasional, Vol.22 No.2.

Soedjana, Treppy D., 2005, "Prevelensi Usaha Ternak Tradisional dalam perspektif peningkatan produksi ternak nasional. Pusat Penelitian dan Pengembangan Peternakan", Bogor: Jurnal Litbang Peternakan, 24(1). 
Nasrudin, Edhi Martono, Subejo -- Peran Sarjana Membangun Desa (SMD) Dalam Peningkatan Ekonomi Masyarakat Dan Implikasinya Terhadap Ketahanan Ekonomi Masyarakat (Studi Pada Kelompok Peternak Gunungrejo Makmur, Kabupaten Lamongan - Jawa Timur)

Subekti, Imam, 2016, "Manajemen Koperasi Dalam Rangka Pengelolaan Hutan Rakyat dan Pengaruhnya Terhadap Ketahanan Ekonomi Masyarakat (Studi pada Koperasi Wana Lestari Menoreh di Kabupaten Kulon Progo, DIY)", Jurnal Ketahanan Nasional, Vol. 22 No.2.

Syarbini, Husin dan Priyono, Joko, 2014, Strategi Mengubah Usaha Kecil Minim Menjadi Kaya Miliaran, Solo: PT. Tiga Serangkai Pustaka Mandiri.

Tambunan, Tulus, 2002, Usaha Kecil dan Menengah Indonesia, Jakarta: Salemba Empat.

Terry, George dan Leslie W. Rue, 2010, DasarDasar Manajemen, Cetakan kesebelas, Jakarta: PT Bumi Aksara.

Yusuf, Ilma Fatimah, 2016, "Peran Pemuda Dalam Pengembangan Eduwisata Energi Terbarukan dan Implikasinya Terhadap Ketahanan Ekonomi Wilayah (Studi di Desa Poncosari Kecamatan Srandakan Kabupaten Bantul Daerah Istimewa
Yogyakarta)", Jurnal Ketahanan Nasional Vol. 22 No.3.

Zulkarnain, Muhammad Iskandar, 2015, "Peran Balai Pemuda dan Olahraga Yogyakarta Dalam Upaya Pengembangan Kewirausahaan Untuk Mendukung Ketahanan Ekonomi Keluarga (Studi Tentang Persepsi Peserta Kegiatan Pelatihan Ketrampilan BPO DIY)", Jurnal Ketahanan Nasional, Vol.21 No.3.

\section{Peraturan Perundangan}

Republik Indonesia, Undang-Undang No. 18 Tahun 2009 Tentang Peternakan dan Kesehatan Hewan.

\section{Lain-Lain}

Buku Laporan Tingkat perkembangan desa tahun 2015 Desa Gunungrejo

Buku Laporan Profil Desa Gunungrejo tahun 2015

Buku Profil Kelompok Peternak Gunungrejo Makmur tahun 2015 